\title{
Introduction to the academic perspectives of CSR measurement
}

\author{
Patricia Martínez García de Leaniz*, Ignacio Rodríguez del Bosque \\ Faculty of Economics and Business Studies, University of Cantabria, \\ Avenida de los Castros S/N, 39005 Santander, Spain \\ *E-mail address: martinezrp@unican.es
}

\begin{abstract}
There is much interest and a growing number of studies on the measurement of what is known as corporate social responsibility (CSR). This growing attention is mainly due to the inexistence of unanimity with reference to its measurement due to the large amount of research on this topic. This lack of consensus requires an exhaustive study of the different methods for measuring this notion, so as to clarify and identify the main limitations of each of them, in order to advance knowledge on the current state of CSR.
\end{abstract}

Keywords: Corporate Social Responsibility; measurement

\section{INTRODUCTION}

The role of business in society and the relations between organizations and society have been discussed extensively since the beginning of capitalism. In this sense, the notion of Corporate Social Responsibility (CSR) has become one of the most important concepts in the academic literature. CSR means that organizations take on responsibility towards others in society, not only on their shareholders and customers [15]. CSR calls for companies to take their social and environmental responsibilities as seriously as they pursue their economic objectives. A problem surrounding this concept is its measurement. Despite the existence of several methods in the academic literature, most of them have limitations $[1,16,27]$. Therefore, it is necessary to delve into this aspect for the correct understanding of the state of CSR in our days. Thus, the purpose of this paper is to fill this gap in knowledge by performing a detailed study of the different methodologies used for CSR measurement.

\section{LITERATURE REVIEW: ACADEMIC PERSPECTIVES OF CSR MEASUREMENT}

There is no single way to measure CSR activities. In order to shed some light in this area, Maignan and Ferrell (2000) categorized the existing alternative methods into three main approaches: (1) expert assessments, (2) single or multiple indicators, and (3) surveys of management. The first category has evaluated corporate social performance based on information provided by both industry experts and experts in the business or society area. With regard to this, several studies have measured CSR with reputation index and databases, which 
requires executives to assess the extent to which specific companies operating in their own sector behave responsibly towards the environment and the community.

Regarding the second category, some researchers have used more objective indicators in order to avoid the subjectivity inherent in evaluations of experts. For instance, Bragdon and Marlin (1979) used a pollution control index published by the Council of Economic priorities. Other researchers have considered corporate criminality as an indicator of CSR [2]. An increasing number of studies incorporate several types of measures [24, 26]. Griffin and Mahon (1997) combined four estimates of CSR: the Fortune reputation index, the KLD index, the Toxic Release Inventory (TRI), and the rankings provided in the Directory of Corporate Philanthropy.

As far as the third category is concerned, a number of scholars such as Aupperle et al. (1985) asked respondents to express their level of agreement or disagreement with twenty statements about social responsibilities of businesses. These authors then argued that the answers were reflective of the commitment to corporate social responsibility shown by the organizations employing the respondents. Other surveys conducted to date have also focused on perceptions of CSR activities and not on corporate behaviors [22, 23].

Based on Turker (2009) and expanding this classification, the following approaches are considered feasible for measuring CSR: reputation indices, databases, single and multiple indicators, content analyses of publications, and measurement frameworks at the individual and organizational levels. Reputation indices and databases are among the methods used to assess socially responsible activities. The Fortune reputation index, the index developed by Kinder, Lydenberg and Domini (KLD), and the Canadian Social Investment Database (CSID) are examples. A limitation of the indices is that the utilized aspects are not based on theoretical arguments (Maignan and Ferrell 2000). Similarly, the databases only consolidate information from firms in a specific market; thus, they have a narrow evaluation range [27].

As mentioned before, the third proposed alternative method is to use both onedimensional indicators as the pollution control rate [4] or the rate of corporate crime [2,9] and multidimensional indicators [14,24,26]. However, even overcoming the limitation of the first group in terms of unidimensionality and using the second set of indicators, this approach still presents a serious limitation when encompassing the entire structure of CSR [16]. As these authors suggest, the indicators used may not be representative of the same underlying construct.

Another method is the content analysis of publications. Recently, CSR information has become more accessible as a result of the growing attention that companies give to the disclosure of their socially responsible practices [13]. Nevertheless, the information in a corporate report may be different from the activities that were actually performed [19]. Therefore, the reliability of the companies may be an important limitation. Another approach to the measurement of CSR is to interview members of the organization. The main limitation of this research is that it assesses the commitment of individual directors, and, therefore, it is not possible to estimate the socially responsible practices adopted by companies as a whole. Other surveys have focused on managers' perceptions of CSR and not on business behavior $[22,23]$.

The sixth method is based on the use of scales that measure the perception of CSR activities by individuals. Whereas the above methods attempt to measure the actual performance of CSR, this method measures the perceptions that stakeholders have of the concept. Among the most outstanding academic developments in this group are models of corporate associations [5], the pyramid developed by Carroll $(1979,1999)$, models focused on the theory of interest groups $[8,10,18,27]$, and those based on the theory of sustainable development $[3,20,21,28]$. The models described almost entirely coincide in highlighting the 
perception of CSR as a multidimensional construct while differing significantly in both the number of dimensions and the component factors.

Among the academic developments that pose CSR as a multidimensional construct, the work that has become increasingly accepted and has been used by several authors, both theoretically and empirically $[12,16,18]$ has been that proposed by Carroll in 1979 and revised in 1999. Carroll argues that CSR includes society's economic, legal, ethical, and philanthropic or voluntary expectations of organizations at a given point in time. According to this model, there are four interrelated dimensions of CSR. The economic dimension refers to society's expectation that companies be profitable and that they are rewarded for their efficiency and effectiveness in the production and sale of goods and services. The legal dimension is understood as the societal expectation that businesses achieve their financial goals within the confines of the legal framework. The ethical dimension refers to society's expectation that business practices meet certain ethical standards. Finally, the discretionary or philanthropic dimension relates to society's expectations that companies will voluntarily involve themselves in roles to address social needs.

Carroll's model, as well as other less established frameworks, such as the corporate associations described by Brown and Dacin (1997), have not been subjected to scrutiny by stakeholders and consumers [17], and the study of these models has usually been based on definitions provided by company directors $[1,25]$ Thus, little is known about consumers' perceptions of CSR $[3,12,17,25]$ or to what extent this framework and its dimensions properly reflect the perceptions of this group of stakeholders.

A second approach is based on the postulates of the theory of interest groups [11]. According to this proposal, the components of CSR should be classified according to those interest groups that benefit the most from them and are the main target audience of each action. Following this approach, the literature has identified various dimensions of CSR: consumers, employees, shareholders, society in general, the environment, and the market, among others $[10,18,27]$. This model is not without its critics, and there are studies that indicate its limitations [27]. The main limitation described in these studies is that the research conducted in this area has taken into account only a limited number of target audiences and not all of the stakeholders of the companies. Finally, a third perspective on the measurement of CSR proposes a focus on sustainable development $[3,20,21,28]$. From this perspective, the concept of CSR is reinforced as a multidimensional construct that equally emphasizes economic, social, and environmental aspects.

\section{CONCLUSION}

Starting from current research this paper focused on the question how to measure CSR activities. A review of the literature reveals the existence of different methods for measuring socially responsible actions. Although all of these methods have contributed to the literature on CSR, they all have limitations. However, there are several scholars who support CSR measurement scales as a proper methodology since they feel that_other measurement methods may collect issues that consumers and other stakeholders cannot assess, as it is difficult for them to acquire and memorize information about social responsible companies. 


\section{ACKNOWLEDGEMENT}

This research was funded by the FPU Scholarship Program provided by the Spanish Ministry of Education, Culture and Sports.

\section{References}

[1] Aupperle K., Carroll A., Hatfield J., Academy of Management Journal 28(2) (1985) 446-463.

[2] Baucus M. S., Baucus D. A., Academy of Management Journal 40(1) (1997) 129-1511.

[3] Bigné E., Andreu L., Chumpitaz R., Swaen V., Universia Business Review 5 (2005) 14-27.

[4] Bragdon J. H., Marlin J. A., Risk Management 19 (1972) 918.

[5] Brown T., Dacin P., Journal of Marketing 61(1) (1997) 68-84.

[6] Carroll A. B., Academy of Management Review 184 (1979) 497-505.

[7] Carroll A. B., Business and Society 38(3) (1999) 268-295.

[8] Clarkson M., Academy of Management Review 20(1) (1995) 92-117.

[9] Davidson W. N., Worrell D. L., Akron Business and Economic Review 21 (1990) 7-19.

[10] Decker O. S., Managerial Auditing Journal 19(6) (2004) 712-728.

[11] Freeman R. E., Strategic management: A stakeholder approach. Boston, MA: Pitman, 1984.

[12] García de los Salmones, M., Crespo A., Rodríguez del Bosque I., Journal of Business Ethics 61(4) (2005) 369-385.

[13] Gray R., Kouhy R., Lavers S., Accounting, Auditing and Accountability Journal 8(2) (1995) 47-77.

[14] Griffin J. J., Mahon J. F., Business \& Society 36(1) (1997) 5-31.

[15] Holloway C. J., Marketing for tourism, Harlow: Prentice Hall, 2004.

[16] Maignan I., Ferrell O. C., Journal of Business Ethics 23(3) (2000) 283-297.

[17] Maignan I., Ferrell O. C., Journal of Business Research 56(1) (2003) 55-67.

[18] Maignan I., Ferrell O. C., Hult G. T. M., Journal of the Academy of Marketing Science 27(4) (1999) 455-469.

[19] McGuire J., Sundgren A., Schneeweis T., Academy of Management Journal 31(4) (1988) 854-872.

[20] Panapanaan V., Linnanen L., Karvonen M., Phan V., Journal of Business Ethics 44(2) (2003) 133-148.

[21] Panwar R., Rinne T., Hansen E., Juslin H., Forest Products Journal 56(2) (2006) 4-12.

[22] Pinkston T., Carroll A., Journal of Business Ethics 13(3) (1994) 157-169. 
[23] Singhapakdi A., Kraft K. L., Vitell S. J., Rallapalli K. C., Journal of the Academy of Marketing Science 23(1) (1995) 49-56.

[24] Stanwick P., Stanwick S., Journal of Business Ethics 17(2) (1998) 195-204.

[25] Swaen V., Chumpitaz R., Bigné E., Andreu L., Being a socially responsible company: What does it mean for European young consumers?, Paper presented at 32nd European Marketing Academy Conference, Glasgow, United Kingdom. May, 2003.

[26] Turban D. B., Greening D. W., Academy of Management Journal 40 (1996) 658-672.

[27] Turker D., Journal of Business Ethics 85(4) (2009) 411-427.

[28] van Marrewijk M., Journal of Business Ethics 44(2) (2003) 95-105. 